\title{
一般演題抄録
}

$$
\begin{gathered}
\text { ロ 演 } \\
\text { ポスターセッション }
\end{gathered}
$$


1 ポリオウイルス受容体の体内分布に基づいた

ウイルスの組織移行性の機擈論的解析

○是切勇思、寺䐀哲也、田辺修一、*青木淳賢、*小池智、**白木和子、 **野本明男、杉山雄一：東大·薬・製戍、*東京都臨床研·微生物、

**東大・医科研・ウイルス

【目的】ウイルスの組織移行機樍を解明することで遺伝子やペプチド性薬物のターゲティン タに新しい知見が得られる可能性がある。本研究は、ボリオウイルス(PV)の組織移行特性とウイ ルス受容体(PVR)の分布特性との関係を明らかにすることを目的とした。

【方法】 PVはSabin 1 株 ${ }^{35} \mathrm{~S}$ 標職体)を用いた。PVRはヒト型( hPVR)、及びヒト型と相同性が高 いがウイルス非結合性のマウス型(mPVR)を対象とし、その分布特性は抗PVRモノクローナル抗体 (それぞれ $\left.{ }^{125} \mathrm{I}-\mathrm{P} 286,{ }^{125} \mathrm{I}-1 \mathrm{D} 8\right)$ を用いて評洒した。実検動物は正常マウス(ICR)及びhPVR遺伝子を導 入したトランスジェニックマウス $(\mathrm{Tg} 21)$ を用いた。

【結果・考察】PV及びP286を Tg21に静注後の見かけの組織対血槳中浱度比(Kp,app)は、組織閩 で約1000倍の違いが見られ、两者に良い相関性があった。一方、PVをICRに静注後の值は約10倍 の違いであった。1D8をICRに静注後のKp,appは、P286を Tg21に静注後の值と肝满、脾䑏を除く 組織閵でほほ良い相関性加見られた。ウイルス感染の初期段階である組織移行過程において、ウ イルス受容体分布特性がウイルス組織移行特性の支配要因であることが示唆された。

2 モノクローナル抗体一カルボブラチン重合物の重合效率、抗体活性並

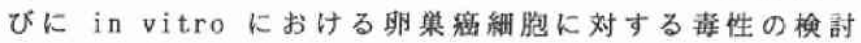

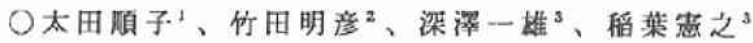

${ }^{1}$ 千葉社会保俛病院産㛺人科

${ }^{2}$ 千莱大学医学部第二外科、 ${ }^{3}$ 同産科婦人科

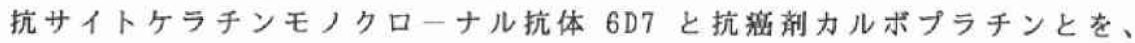
テキストランを介し架橋剂を用いて重合させ、その重合効率、抗体活性並ひに

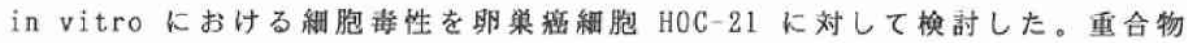
中カルボブラチン浱度は原子吸光法にて測定し、抗体量との比率を算出した。 抗体活性は抗原吸着ヒースを用いた BIA 法にて、また細胞犎性はコロニー形 成法にて趾価した。桖々の比率で重合操作を行い、抗体/薬物最大重量比 1 : 450 を得た。架橋剂量を增量しても重合奻率は上并しなかった。抗体活性は重 合された永物最が多い程低下する傾向を示した。コロニー形成法において、重 合物の細胞金性は薬物単独の場合とほほ同等であり、滣度依存性であった。本 法により極めて奻率良く重合が出来、然も重合摷作後に抗体活性の低下を認め るものの他の重合法と比较して有意に高くはなく、薬物活性は損なわれないこ とが判明した。 


\section{帝京大・薬○滰沢知子 丸山一雄} 晹田勉岩鳰素治

【目的】ポリエチレングリコール (PEG)を付与したリポソームは、「ステ ルスリポソーム」と呼ばれ、細絡内皮系 (RES)取り込み回避による高い血中 滞留性を示す。PEGの先端に抗体を付与し、より高い夕ーゲッティング特性 を持つステルスイムノリポソームの開発を目的とした。【方法】PEGの一端に phosphatidylethanolamine(PE)を結合し、他端にカルボキシル基を導入し たPE-PEG- $\mathrm{COOH}(\mathrm{a})$ を合成した。ePC: CH(2:1, m/m)に (a)を $6 \mathrm{~mol} \%$ 共存さ せてリポソームを調製し、カルポジィミド存在下で抗体を反応させた。抗体に はマウス肺血管内皮細胞に対するモノクローナル抗体 $34 \mathrm{~A}$ を用いた。【結果】 $34 \mathrm{~A}$ が䄪 30 分子結合したステルスイムノリポソームは $60 \%$ 肺へ結合した。従 来のイムノリポソームに比へ、抗体の少ない付与量にもかかわらず高い夕ーゲッ ティング特性が得られた。これはPEGによるRES取り込み回避と、抗体か PEGの先端に位置したために立体障害が無くなったためと考察された。

アンチセンスDNAの受容体を利用したテリバリーは、数多く報告されている。 しかしテリハリー効果の評洒はアンチセンス効果で行われている場合が多く、 アンチセンスDNAの取り込みによりテリバリー効果を呼洒した例は少ない。そこ で、アンチセンスONAのテリハリーとしての成功例が報告されているasialoglycoprotein (訮特異的に発現しているasialoglyooprotein受容体のリカンド) とDoly-L-1ysine(アンチセンスDNAと静電気的な結合をすることが報告されて いる)の結合体、即ちラクトース攸飾BSAとD01y-L-1 y sineの結合体をヒト ICAMー1に対するアンチセンスONAのキャリャーとして合成し、ラット肝細胞を用 いアンチセンスONAの取り込みの謤価を行った。更に最道キャリャーの性状にっ いて速度韵モテルに基ついた教察を行ったので併せて㫰告する。 
5 ガラクトース修飾ポリ - L - グルタミン酸を利用した肝実質細胞への薬物ター ゲティング

京大・薬 ○平林英樹、西川元也、高倉喜信、橋田 充

我々は、肝実質細胞が有する䌅鎖認識機構に基つくく細胞特異的な薬物ターゲティング に関して系統的な検討を行い、既にデキストランをバックボーンとする新規キャリヤー システムや、タンパク質分子に直接糖修飾を施した誘導体を開発している。今回は化学 修飾が容易でかつ生体内分解性が高く薬物放出にも有利と考えられるポリ - L - グル夕 ミン酸 (PLGA) を取り上げ、そのガラクトース修飾体を合成してモデル薬物ビタミン $\mathrm{K} 5\left(\mathrm{VK}_{5}\right)$ の肝ターゲティングのキャリヤーとして応用する可能性について検討した。 ガラクトース修飾 PLGA はその裾修飾率の上昇に伴い肝への移行量が增大し、䌅含量約 $12 \%$ の高修旍体では投与後 10 分間に $60 \%$ 以上が肝実質細胞に特異的に取り込まれた。 また、高修飾 PLGA に VK 5 を結合させた場合でも同様に効率良く肝実質細胞に取り込 まれたことから、ガラクトース修飾 PLGA が肝実質細胞への薬物ターゲティングのため の有用なキャリャーとなり得ることが示された。

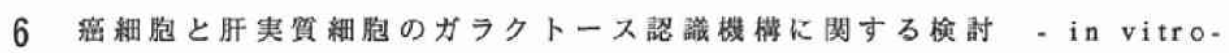

山本正幸 ${ }^{1} 、 川 \square$ 和久 ${ }^{2} 、$ 一瀬浩郎 ${ }^{1}$ 、松川俊 -1 、 高須腾也 ${ }^{1}$ 、大姆教昭 ${ }^{2}$ 、石井伸子 ${ }^{2.3}$ 、小路敏彦 2.3 、 萧松隆之 ${ }^{1}$

1) 長崎大学医学部第2 外科 2) 長崎大学薬学部臨床薬学科

3) 長崎大学保健管理センター

我々は、これまで本学会において、ラクトースを通入した多槽被覆リポソー ムの肝癌を含む各種癌細胞への選択的取り込みと、アドリアマイシン封入によ る抗原壆効果の增強を、invitro及びinvivoにおいて報告してきた。今回、 我々は、肝細胞へガラクトースレセブターを介して取り込まれるPoly (vinyllactonamide-co-viny $1 \mathrm{mal}$ tonamide) ( Poly (VLA-co-VMA)) を用い

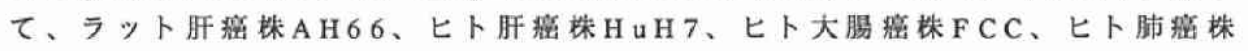
KNS、及び肝実劦紐胞への取り込みについて比較検封した。肝細胞への Poly (VLA-co-VMA)の培瓷後 3 時間での取り込みは、ガラクトース（VLA） の峃入率の增加と伴に、上昇していき、道入率 $50 \%$ でほぼブラトーに達した。 しかし、Poly (VLA-co-VMA)の4種類の癌細胞への取り込みは、ガラクトー ス（VLA）の祭入事が $90 \%$ におても、まったく認められなかった。従って、 ラクトース修笁リポソームの選択的取り込みは、肝細胞に存在するガラクトー スレセプターを介した取り込みとは、異なる認啔機棬によることが示唆された。 
7 ガラクトース結合インターフェロンの肝集積性と薬効

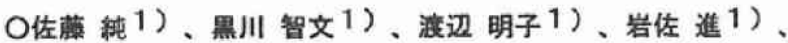
小川 泰亮1)、戸口 始 2)

1) 武田薬品、DDS 研究所、2) 武田薬品、ROR研究部

[目的] インターフェロン ( I F N ) の肝滕への骤的化によりウイルス性肝炎の治㩧係数 の改箁を目的とした。[方法］L e e らの方法により活性化Th i o g a I a c t os i

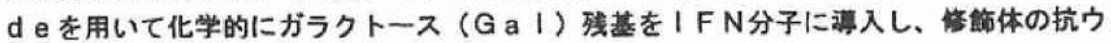

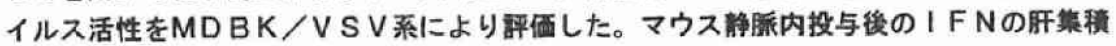

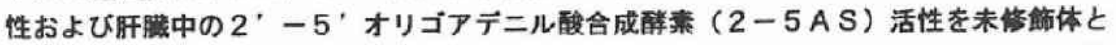

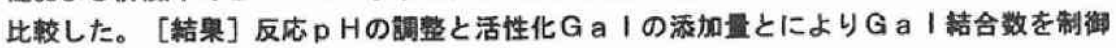
した。結合数の增加とともに|FNの抗ウイルス活性は低下したが、4分子導入体（（G

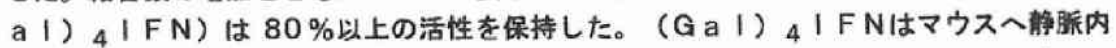

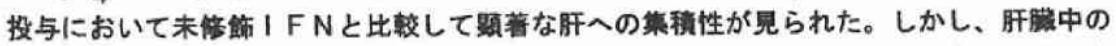
2-5 A S 活性の增強効果は見られなかった。[考察] 投与された $G$ a I 結合 I F Nの大 部分は肝英賽細胞の G a I レセプターに結合後、速やかに細胞内に取り込まれ、IF N レ セプターに結合し得ないと推瞌される。

8 腎指向性担体としてのポリグルタミン酸の利用

ディ・ディ・エス研究所

○権正 晃德、野草 秀夫、菅原 民雄、奥野 哲

我々は、すでにガラクトース修飾ボリアミノ酸が肝䑏へのターゲティンク担体となり得ることを

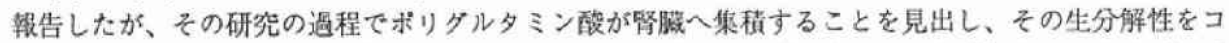
ントロールすることにより㹂䏼へのターダティング担体として利用することを考えた。D-およびLータ ルタミン酸モノマーより合成したボリ-D-ダルタミン酸(PDG, MW:10,600)、DL比50:50のポリ-DL-ダ ルタミン酸(PDLG<1:1>,MW:12,000)、DL比24:76のボリ-DL-グルタミン酸(PDLG<1:3>,MW:10,800) および市販のポり-L-ダルタミン堙(PLG, MW:13,300)の4種にTyramineを導入後ヨードラベル化し、

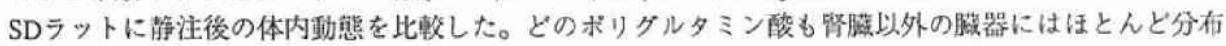

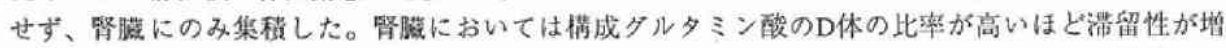
し、尿中排泄は抑えられた。投与後30分までの尿には高分子が多く存在するものの、6 時間以降の尿 中にはどのボリクルタミン酸も大部分が低分子として排泄された。PDLG<1:1>を用いた㹂婼のミク

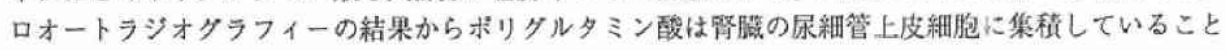
が確諗された。

従って、ボリグルタミン酸は、その構成ダルタミン酸のDL比を変えることにより生分解性がコント ロールでき、腎䑏へのターゲティング担体となり得ることが示唆された。 
9 肺癌の綎隔リンバ節転移に対するLip-ADMを用いたDDSの実験的検討

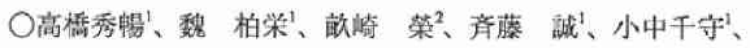
細田順一 ${ }^{2}$ 、加藤治文 ${ }^{1}$ (東京医科大学・ 第一外科、梁蕌剂部)

進行肺癌の繸谝リンバ節転移の治療を目的として、アドリアマイシン封入リ ボソーム（Lip-ADM）を用い、その投与経路及び有用性を実験的に検討し、そ の臨床応用の可能性を㭘討した。

体重15 20kgの成犬を用い、投与経路は静脈内投与、左胸腔内投与、経気管 的気管分岥部下リンバ節投与の 3 種とした。ADMの濃度はHPLCで测定した。 静脈内投与、胸腔内投与にはLip-ADMをFree-ADMと比渂し、その血清中の

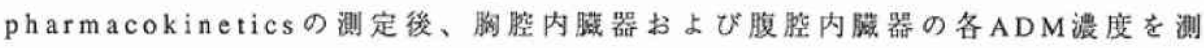
定した。経気管的気管分岐部下リンバ節投与では血清中のpharmacokinetics

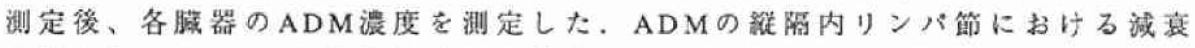
曲線から、ADMの有効作用時問を検討した。組織病理学的検討も合わせて行。

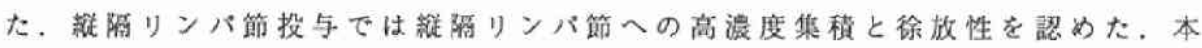
法は術前・術後肺癌の䋨隔リンバ節転移の治療に有用と考えらた。

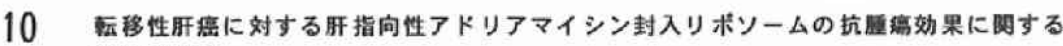

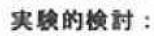

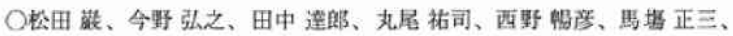

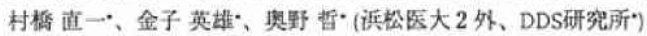

[目的]我々はremote loading法によるアドリアマイシン(ADM)封入リポソーム(Lip ADM)の有用性を報告してきた

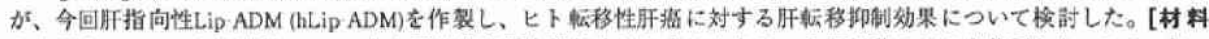

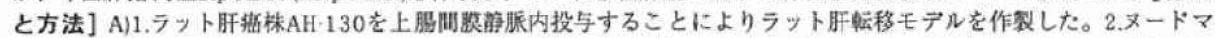

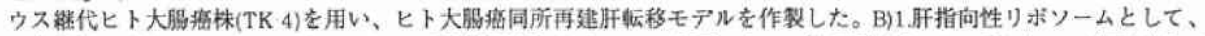

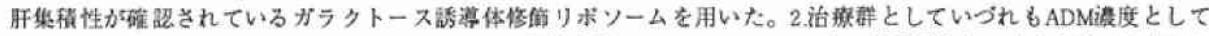
$5 \mathrm{mg} / \mathrm{kg}$ のADM(Free ADM)、Lip-ADM (cLip ADM)、肝指向性Lip ADM (hLip ADM) 妾、対照群として生食水を 4 日每に 3

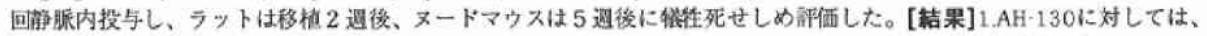

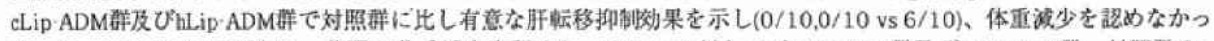
た。Free-ADMは4/10死亡し，苦明な体重娍少を認めた。. 2.TK-4に奶してはcLip-ADM群及びhLip-ADM群、対照群の3

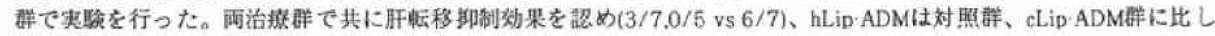

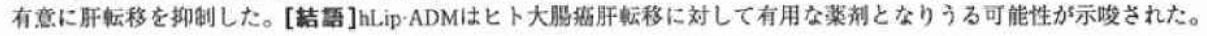


11 アシアロフェッイン修飾リボソームによる初代培養肝実質細胞への寈伝子の導入

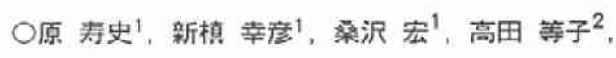

小池 克郎 ${ }^{2}$ ，土屋 睛嗣 1

東京葉大·宓， ${ }^{2}$ 密研究会癌研究所

アシアロフェツイン修飾リボソーム (AF-I i posome) による培盖細胞系への受容体を介した pCMVB DNAの薄入について，ラットの初代培養肝実领細胞を用いて挨討した。

[方法]界面活性剂除去法と凍結融解法を組み合わせた方法により, PCMY $\mathrm{DNA}(7.2 \mathrm{~kb})$ をPC:DOPE:

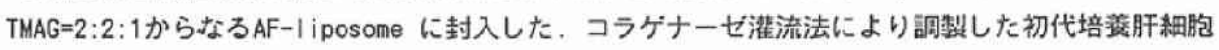
に棌加してトランスフェクションを行なった後、細胞に産生された $\beta$-galactosidaseの活性をo-nitropheny I- $\beta$-D-galactopyranosideを基䉢とした比色法により测定した .

【結果·考察】初代培筑肝細胞におけろアシアロ糖蛋白レセブターを介したAF-1 iposomeの取り込み はHepG2細胞に比して大であったにもかかわらず, $\beta$-galactosidase遺伝子の発現は低レベルであっ た、しかし、幼若ラットより調整した初代培㪈肝細胞において高い発現が認められ，さらにインス リンや EGFを培地に湫加すると発現が增加した．以上の結果から，培羡細胞系における外来遺伝子 の発現には細胞が增殖期にあることが重要であると考えられる。

12

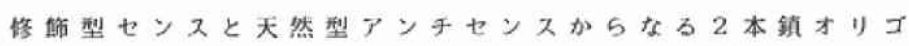
ヌクレオチトの安定性と生体内動態

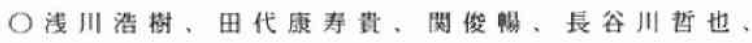

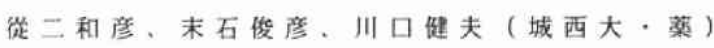
太田尚志, 実吉落郎 (西東京科学大・ハイオ)

[目的]アンチセンスオリコヌクレオチドの生体内での安定性と細胞㯖透過 性の改善を目的として、リン酸シエステル骨格への化学修飾が行われている。 しかしながら、これら誘道体では買性体の出現や摽的センスとの視和性の低下 なとが問題となっている。本研究では天然型のリン酸シエステル構造を有する オリコヌクレオチトの安定性の向上と生体内動態の改曾を目的として、化学修 飾を施した相補的オリコを分子キャリアーとして用いる可能性を橹討した。

[方法] 標的遭伝子のモデルとして C A T の開始コドンょり下流1 5 × 21 塭 基配列を碏択した。キャリアー例の修饰として (1)ホスホロチオエート、(2)末端

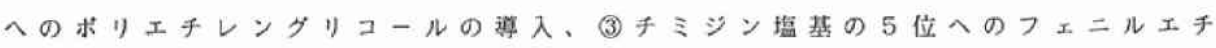
ル基の導入を行った。【繥果]恪飾型一天然型 2 本镍オリ】は血清中および各 種ヌタレアーゼ存在下での安定性が向上した、また、 $\mathrm{T} \mathrm{m}$ 值の变化から修踇型 一天然型 2 本簃オリコから天然型一天然型への組替えが示唆された。 
13 䣫酸を溶媒とした $5-\mathrm{F} U$ 含有マイクロスフェアーの作製と放出制御の 検討

○尾崎公彦" ’、佐々木定之、辻本洋行、大山贵之、 椎原次夫、萩原明於、高橋俊雄、立 丞烋 ${ }^{2}$ 、筏 義人（京都府立医大第一外科 ${ }^{2}$ ， 、京大生医工研 ${ }^{21}$ )

乳酸ークリコール酸共重合体をマトリックスとしたマイクロスフェアー作製 に際し、薬効成分とマトリックスの溶媒として従来用いられていたジメチルホ ルムアミト ( D M F ) は毒性があるために、マイクロスフェアー内での残留性 が問題であった。

この問題を解決するためにD M F に代えて毒性のない酢酸を用いて、5-F U 含有マイクロスフェアーを試作し、その放出制御の検討を行った。

酢酸を溶媒とした $0 / 0$ 型乳化法による液中乾燥法で作製した 5 -F U 含有マ イクロスフェアーの走査電顕によると、直径が数 $\mu \mathrm{m} \sim 200 \mu \mathrm{m}$ のマイクロ スフェアーを含有し作製条件により比較的自由に調製することができた。

In vitroの溶出実験では、24 時間後の $5-\mathrm{F}$ U の溶出量は約 $40 \%$ と初期バー ストは抑制された。その後約 2 週間で $100 \%$ の溶出を認め、放出制卸の点で もすぐれていた。

14 ラット卵鉴癌に対する C D D P 含有乳酸グリコール酸共重 合体マイクロスフェアー腹腔内投与の基整的検討

○版谷晴介、杉山微、牛的公生, 片阔明生, 西田敬,

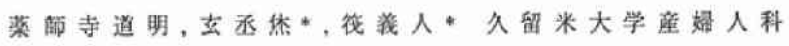
京都大学生体医丵工学研究七ンター・

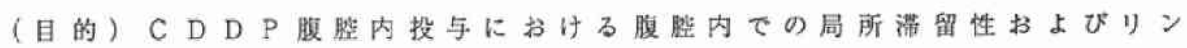
バ節人の薬剂移行性の改善を目的として、C D D P 合有乳酸グリコール酸共重合

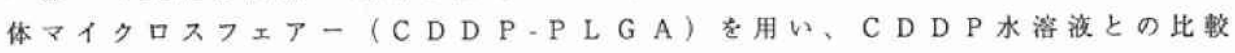

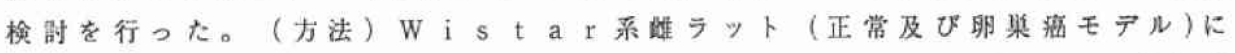
$2.4 \mathrm{~m} \mathrm{~g} / \mathrm{kg}$ の C D D P - P L G A 及びC D D P 水楁液を腹腔内に投与し、投与後 の血消中及び各組織中の白金漫度を測定した。さらに、塐性に開しての比較㭘討 のため C D D P - P L G A 及び C D D P 水溶激を各種搌度を設定して投与した。

(結果) C D D P 水溶液に比へ C D D P - P L G A は股腔内で局所滞留性に優 れており、逆に全身への移行は少なかった。また、蒋性に関してＬD５0ではC D D P - P L G A C D D P 水溶液の3 倍以上を示し安全面上り C D D P に打 る d ○ s e u p か可能と推測され治症への応用が期待される。 


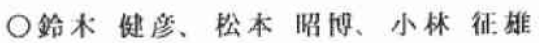

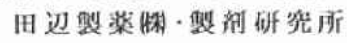

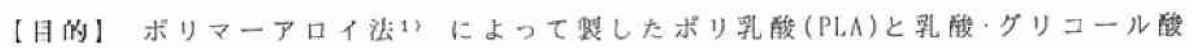

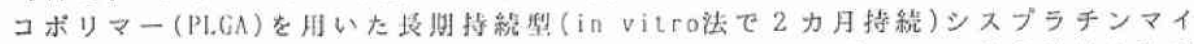

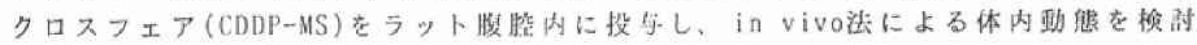
した。

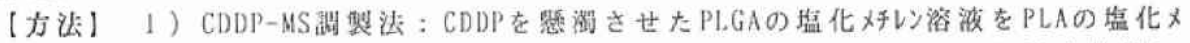

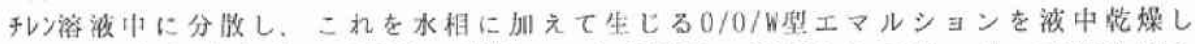

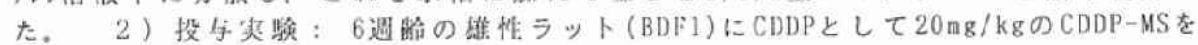

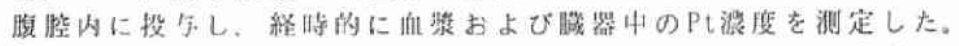

【結果】ポリマーアロイ法により得られたCDDP-MSは、0次型、シクモイド型など

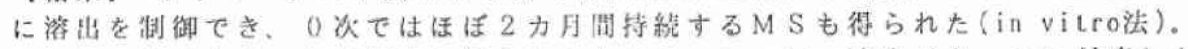

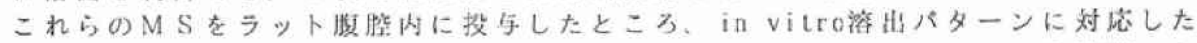

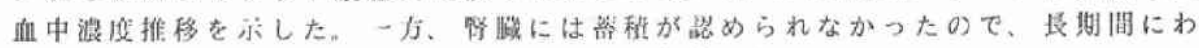
たり刷作朋を排えて、夘果の持続することが畞待できる。

1) 日代燕学全114年会要旨炛(1994)

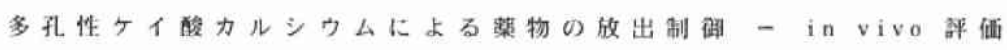

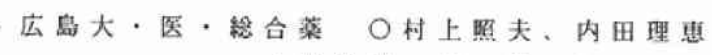
中川美栈、東豊、矢田登

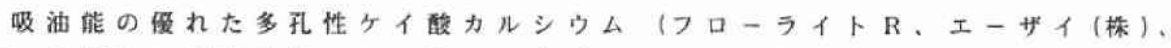
FR) を菜物の保持担体として用い、家鬼への経口投与又はラット皮下への值込 を行いinvivoにおける蓃物の放出持続性を秤価した。経口ではSulfamethizoleを、植込では分子量の程々翼なるFITC-Dextransをモデル薬物として

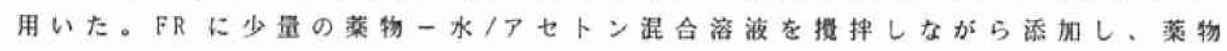

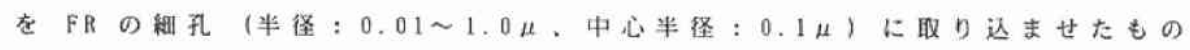

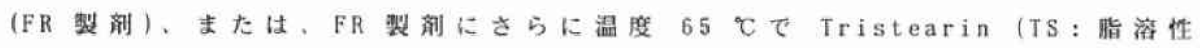

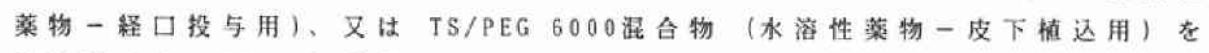
取り込ませ、FRの細孔をシールしたものを用いた。家鬼経口における㩰物の

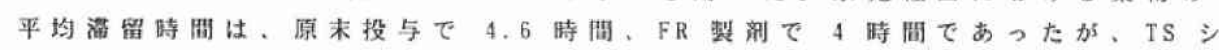

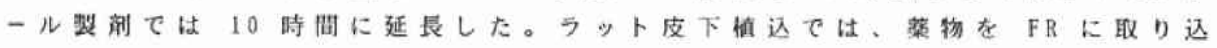

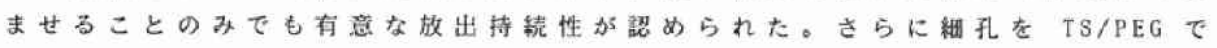
シールした列剂に於ては、1ォ月に渡る持紿放出が䎑められた。 
17 カルシウム濃度応答型薬物放出特性を有する自己硬化型 リン酸 カルシウムセメントのin vivo薬物放出

神戸藥大 ○大塚 誠、中東吉則、松田芳久 東大薬 杉山雄一、ユタ大·薬 W. I. Higuchi

(目的) 生体内物質であるHydroxyapatite(HAP)に転移する自己硬化型りン酸カルシ ウムセメントは生体中で骨と同様に体液中のカルシウム淟度の影帮を受けることが知 られている。この特性を生体内理め込み型DDSの薬物放出機能として応用し、薬物放 出をカルシウム涨度に低存して制御するインテリジェントDDSの满築を試みた。

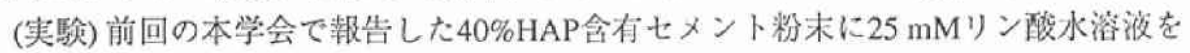
加え練合し、更に $2 \%$ 薬物を加え, $37^{\circ} \mathrm{C}$, 相対湿度 $100 \%$ で24時間保存し硬化させた。in

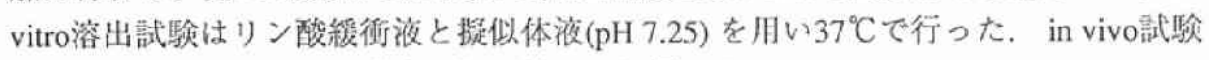
は骨粗整症ラットを用い背皮下埋入法により行った。

(結果と考察) セメントからの in vitro薬物放出速度は溶出液が擬似体液中では抑制 され、リン酸緩衝液中では加速されるという、on-offの薬物放出特性を示した。in vivo試験で骨粗秷症ラットの血中薬物浱度曲線は正常ラットに比較して有意に高いこ とが示された。

18 生体分解性高分子強脱ブラタによるガンシクロヴイルの徐放システム

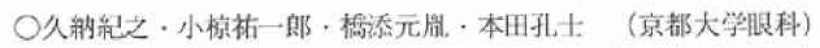
立承休・筏喽人

(京大生休医痖工学研究センター)

サイトメガロウイルス (CMV)絧脱炎は、眼科领域ではAIDSに合併する踓治 性で最も頻度の高い日和見感染症である。抗ウイルス削の全身投与や硝子体内

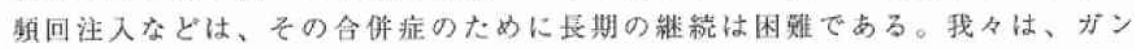
シクロヴイル(GCV)を硝子体内に徐放させることを目的した強膜ブラグを新た 作成し梌㣙した。乳酸グリコール酸共重合体（PLGA，基重合比 75/25, 重 蛊平均分子量 121.0001 より成る GCV $25 \%$ を含有する強顷ブラグを調製した。 in vitro の萎物浴出性、书よひ毛㥞体偏平部に固完した有色家鬼の房水・硝

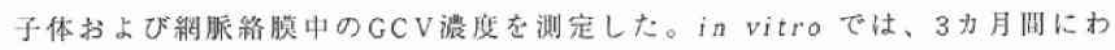
たり GCVを溶出した。2 カ月以上にわたり家鬼の硝子体の GCV 淟度はCMV

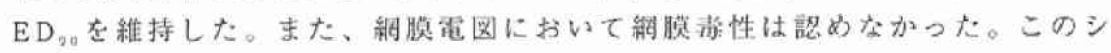
ステムはCMV絪脱炏の治療に有望であると結論された。 
19 生体分解性高分子强脱ブラグによる硝子体算への薬剂赤放システム

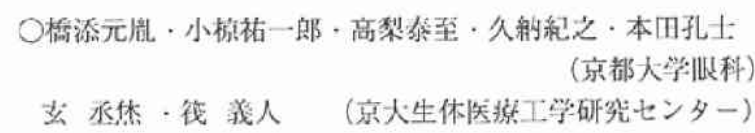

網膜硝子体疾患の治療に際して、硝子体へ菜剂を徐放させるシステムが待ち 望まれている。毛様体扁平部に固定する強膜プラグを考案し、アトリアマイシ ン $(\mathrm{ADR})$ を用いてこのシステムの可能性を検討した。乳酸グリコール酸共重合 体 (PLGA, 共重合比75/25, 重量平均分子量40,000)を用いてプラダを作成し、 invitroの徐放性、有色家鬼を用いた硝子体液濃度の湘定および網膜電図と光 顕レヘルの組織標本にて網膜堆性を検討した。in vitro では 4 週で $26 \%$ の ADR 徐放した。家鬼の硝子体液浱度は約 1 力月間增殖性硝子体絧脱症 ( P VR)の治療域を維持し、網膜毒性も認めなかった。また、同種線維芽細胞 (100000 cells $/ 0.1 \mathrm{ml})$ を硝子体内に注入して実龭的 PVR を作成した。平 均分子量 20000 のブラグは有意にPVRを抑制した $(\mathrm{P}=0.008)$ 。このシステム は網膜硝子体疾患の治療に有望であると結論された。

20

大腸デリバリー技術

一時間制御型大腸デリバリーカブセルー

丹羽 希芳、高谷 智宏、门高田 寞治 (京都薬科大学 薬剤学教窒)

大题潰㿋、大鹏癌などの薬物療法時には循環血流中からの薬物の治療以外に 投薬後、直接に大腸の患部に薬物を作用させることにより優れた治療成績が得 られるものと思われる。そこで経口投与後、胃、小腸では崩壊せず、大腸に到 って崩壊した後、含有している薬物を放出するという機能を有する大腸デリパ リーカブセルの設計を試みた。結合剤あるいはコーティング剤として長年にわ たり錠剤用の賦形剤として使用されてきて安全性の面で問題のないエチルセル ロース (EC) を用いて放出時間制御型のECカプセルを試作した。invitroに おける放出試験およびビーグル犬を用いるinvivoでの試験を行い、本ECカプ セルの放出特性に及ほす要因ーキャッブの膜厚、瞇潤剤の質と量、カプセルボ ティの水透過性ーについて検討を行った。澵潤版を一定とした場合においては、 キャップの膜厚が最も放出時間に対して強い影篦を示した。またinvitroと invivoにおける放出特性の間にも高い相関性がみられた。 